\title{
Becoming White in a White Supremacist State: The Public and Psychological Wages of Whiteness for Undocumented 1.5-Generation Brazilians
}

\author{
Kara Cebulko
}

check for

updates

Citation: Cebulko, Kara. 2021.

Becoming White in a White

Supremacist State: The Public and

Psychological Wages of Whiteness for

Undocumented 1.5-Generation

Brazilians. Social Sciences 10: 184.

https://doi.org/10.3390/

socsci10050184

Academic Editors: Pawan H. Dhingra and Tanya Golash-Boza

Received: 16 March 2021

Accepted: 6 May 2021

Published: 20 May 2021

Publisher's Note: MDPI stays neutral with regard to jurisdictional claims in published maps and institutional affiliations.

Copyright: (C) 2021 by the author. Licensee MDPI, Basel, Switzerland. This article is an open access article distributed under the terms and conditions of the Creative Commons Attribution (CC BY) license (https:/ / creativecommons.org/licenses/by/ $4.0 /)$.
Faculty of Sociology and Global Studies, Providence College, Providence, RI 02916, USA; kcebulko@providence.edu

\begin{abstract}
This study draws on in-depth and longitudinal interviews with twenty-nine 1.5-generation Brazilian immigrants, all of whom can pass as white and experienced illegality in young adulthood. I argue that they benefit from what W.E.B. Du Bois calls "the public and psychological wages of whiteness". That is, white and white-passing, undocumented 1.5-generation Brazilian men and women can largely navigate public space without being stopped, questioned, arrested, detained and/or deported. Additionally, they benefit psychologically-as they gain confidence due to perceived whiteness, even as their immigration status would render them vulnerable to exploitation in the labor market and deportation. These public and psychological wages of whiteness can facilitate social and material gains. I argue that there are three mechanisms by which they experience the wages of whiteness. First, whiteness brings assumed innocence. Second, white racial solidarity with other whites facilitates opportunities and protection. Third, some 1.5-generation Brazilians actively construct whiteness to accrue the public and psychological wages. These findings challenge the master status perspective of illegality and underscore the importance of an intersectional framework for understanding immigrants' varied experiences with illegality, bringing to light the quotidian, gendered practices and identities that sustain the structures of white supremacy.
\end{abstract}

Keywords: 1.5-generation immigrants; unauthorized migration; whiteness; Brazilian immigrants

\section{Introduction}

"If I'm being treated just based on perception of my physical looks and the way I speak... I definitely get treated better. But if I'm in a situation where I have to put down, you know, my identification, and it has to be my green card-or my citizenship, then I definitely, depending on the person, get treated with a little less respect. You know, and I've heard so many people say racist things on the bus or, you know, at a supermarket, not realizing that I'm an immigrant. And it's kind of ridiculous. So, it's depending on the situation, I'm either treated just like any other immigrant or I'm treated like a white person." - Andrea ${ }^{1}$

With her pale white skin and dark almond eyes, Andrea told me during our second interview that most other people saw her as white and treated her with respect. Moreover, she contrasted this respect with the racism and anti-immigrant sentiment other immigrants often experience in their daily lives. For Andrea, however, it was only in instances when she was explicitly asked for her "green card" or "citizenship" that her illegality became salient and she was treated like "any other immigrant." This discrimination was most salient when applying for college-as she was denied access to in-state tuition and federal grants and loans due to her immigration status. Due to these barriers, Andrea was still pursuing her bachelor's degree at age 28.

Thus, Andrea reports white racial privilege in her everyday life and discrimination due to illegality, discrimination which has negatively impacted her socioeconomic mobility. Similar to the other 98,000 undocumented immigrants who graduate high school each year, Andrea has faced financial and legal barriers to higher education (Zong and Batalova 2019). 
Nonetheless, Andrea's life differs in significant ways from many of her undocumented (and documented) peers of color. Notably absent from my conversations with Andrea over the years were stories of racial discrimination by law and immigration enforcement. She did not recount-in either interview-any negative interaction with the police. Her lack of negative interactions as an undocumented immigrant is particularly striking. After all, over the past few decades, the state has aggressively policed, incarcerated, and killed Black persons and ramped up immigration enforcement, detaining and deporting immigrants, especially immigrants from Latin America and the Caribbean (Alexander 2012; GolashBoza 2011; Golash-Boza and Hondagneu-Sotelo 2013). Yet for Andrea and most of the twenty-eight other undocumented but white (or white-passing) 1.5-generation Brazilians I met during my decade-plus years of research in Massachusetts, they reported few negative or violent interactions with law and immigration enforcement. While some experienced anti-immigrant interactions in their early years in the United States, they reported far fewer instances in adulthood once they had lost their Brazilian accents and became fluent in English. In adulthood, some even reported that white civilians interfered with authorities to protect them.

For Andrea, it was also clear that illegality, whiteness, and gender shaped her experiences in the labor market. While she was blocked from many jobs due to her immigration status (especially ones that required a college degree) and instead, found work in the food and restaurant industry, she avoided the lowest-status jobs (e.g., dishwashing) largely fulfilled by Black and Latinx workers (Restaurant Opportunities Center United 2015). Instead, she drew on both white American and co-ethnic networks to find jobs not associated with illegality. For example, in her early 20s, she worked as a hostess at a fine-dining restaurant, not as a dishwasher or busser. As she told me, these latter jobs at her fine-dining restaurant were jobs that white applicants refused to do because the jobs were stigmatized and "messy", often leaving burns on workers' arms and spills on their clothes. While Andrea did not make as much as money as servers and bartenders did, she was in the "front house" of the restaurant, greeting customers and avoiding the "messy" work (bussing and dishwashing) that other immigrant workers at the restaurant were doing.

The question driving this paper is: what do stories like Andrea and other 1.5-generation undocumented, white-passing Brazilians reveal to us about the intersection of (il)legality and white supremacy? Some scholarship on 1.5-generation undocumented immigrants suggests that immigration status is the master status in their lives, overpowering other social locations (Gleeson and Gonzales 2012; Gonzales 2016). The experiences of Andrea and other white-passing 1.5-generation Brazilians, however, demands that we seriously consider how whiteness shapes experiences with illegality. A more intersectional approach, one first advanced by Black feminists and queer activists of color, requires us to consider how social locations in interlocking systems of domination and oppression operate and to situate these systems in a global and historical context (Cohambee River Collective 1977; Collins 1990; Crenshaw 1991). From the very beginning, capitalism as a global system has valued whiteness and devalued Blackness (Robinson 2000). These intertwined systems of white supremacy and capitalism - along with patriarchy — have been central to colonization and nation-state building projects throughout the Americas (Gott 2007; Jung 2015), shaping contemporary migrants' racial and socio-economic positions in their home countries prior to migration, their reasons for migration, and their experiences as immigrants in the United States, including navigating (il)legality (Cebulko 2018). Brazilians who migrated as part of the first large wave of migration in the 1980s and 1990s were primarily from the middle class in Brazil and thought of themselves as white. They migrated during and after an economic crisis, hoping to secure their positions in the global capitalist system-if not for themselves, at least for their children. While first-generation Brazilians experienced downward mobility as they were undocumented and racialized as non-white (Margolis 1994), they hoped their children would be upwardly mobile and regain status (Cebulko 2013). Thus, this context shapes how 1.5-generation Brazilians navigate illegality as adults. 
I argue that while immigration status was the most stigmatizing identity Andrea experiences, her powerful position in the racial hierarchy provides her and other whitepassing 1.5-generation Brazilians with what Du Bois calls "the public and psychological wages of whiteness." That is, despite their illegality-which renders them deportable and disposable laborers under capitalism (Golash-Boza 2015) — they gain other forms of compensation from simply being perceived as not Black (Du Bois 1935; Roediger 1991) nor as part of a racialized Latinx community, whose brown skin is often conflated with illegality (Chavez 2013). This compensation includes access to public spaces without fear of racial discrimination and violence (public wages) and a sense of confidence that they will be treated with respect in everyday interactions (psychological whiteness), both of which can bring very real social and material gains. These forms of compensation are made possible by assumptions of innocence, white racial solidarity from other whites, and Brazilians' own efforts to accrue benefits-efforts which include gendered presentations of self as white and boundary-making from Blacks and other immigrants from Latin America. In this way, their everyday practices to gain the wages of whiteness links them to the ethnic projects of earlier ethno-racial groups who asserted their whiteness while distancing themselves from Blacks and other stigmatized groups (Bashi Treitler 2013; Brodkin 1998; Ignatiev 1995; Roediger 1991).

In the next section, I begin with the literature on 1.5-generation undocumented immigrants, highlighting the salience of illegality in their lives. I then argue that Du Bois's work on the wages of whiteness offers an important path forward for re-centering white supremacy in thinking about 1.5-generation Brazilians' experiences with illegality. But as we will see, experiences with whiteness and illegality play out in gendered ways for 1.5-generation Brazilians-suggesting a more intersectional approach is needed for understanding the wages of whiteness.

\section{Toward a More Intersectional Approach to Illegality}

Immigration status is an important form of stratification in the lives of 1.5-generation immigrants (Abrego 2006; Cebulko 2014; Gonzales 2016). As youth age into adulthood, an undocumented status becomes increasingly salient due to the hodgepodge of inclusionary laws that grant undocumented youth access to important institutional spaces during childhood-namely schools-while exclusionary laws, policies and practices block them from full membership and access to institutional spaces in adulthood (Abrego 2006; Gonzales 2011; Silver 2012). The Supreme Court's landmark 1982 decision in Plyler v. Doe granted unauthorized immigrants access to K-12 education in public schools. While no federal law prohibits access to college, no federal law guarantees access to higher education either. Instead, each state sets their own tuition and enrollment policies for their public schools. While some states grant in-state tuition, others, like Massachusetts, charge out-of-state tuition (Cebulko and Silver 2016). Unauthorized youth are also ineligible for federal loans and grants. Thus, being undocumented reduces the likelihood that undocumented immigrant youth will graduate from high school and enroll in college (Greenman and Hall 2013). Without the ability to legally work, undocumented young persons are largely relegated to low-wage, physically-exhausting jobs when they complete their schooling (Gonzales 2016).

Deferred Action for Childhood Arrivals (DACA) and other legal dispensations that result in work permits and social security numbers do lead to better paying jobs, especially for those who earned college degrees (Cebulko 2014; Cebulko and Silver 2016; Gonzales et al. 2014; Silver 2018). ${ }^{2}$ But work opportunities for DACAmented youth are uneven across the United States. Some states, like South Carolina, restrict many professional licenses to US citizens, leaving careers as nurses, nail technicians and hair stylists out of reach for DACAmented youth who live there (Roth 2019). Given the blocks to mobility and other barriers to belonging for undocumented youth, some scholars argue that an undocumented status becomes a "master status" in adulthood, overwhelming other aspects of their identities (Gleeson and Gonzales 2012; Gonzales 2016; Gonzales and 
Burciaga 2018). Indeed, Gonzales and Burciaga (2018) argue that an undocumented status is an "exemplar" master status. They write:

"(an undocumented status) is the primary identifying characteristic determining access to rights and to the policy. As such, it is unambiguous. For many individuals, it is the trait that has the greatest importance for their access and participation in society, and it influences nearly every decision and action one might take in her or his everyday life".

(Gonzales and Burciaga 2018, p. 181)

Other scholars, however, have argued that the master status lens obscures the roles of other important social locations, such as race and class, which shape the lived experiences of illegality (Cebulko 2018; Enriquez 2017, 2019, 2020; Valdez and Golash-Boza 2020). As an analytical tool, intersectionality requires that scholars account for how systems of domination and oppression are mutually constituted — and work together-to produce social inequalities (Collins 1990; Crenshaw 1991). If we narrow our focus too much on only one social location, we can miss how multiple power dynamics work together in mutually constituted systems to shape immigrants' lived experiences and perspectives.

For example, scholars have shown that dating and family formation for 1.5-generation immigrants is shaped by gender and illegality (Cebulko 2016; Enriquez 2020; Pila 2016) while experiences with social exclusion for undocumented youth and young adults are shaped by race (Enriquez 2019; Patler 2014). Meanwhile, Cho (2017) demonstrates that work experiences of undocumented 1.5-generation Koreans and Mexicans are conditioned by opportunity structures that vary by their ethno-racial membership. Undocumented Korean young adults, who have the same educational levels and ambitions as their Mexican peers, have access to a broader range of jobs given the large network of Korean employers in California. Thus, while much literature suggests that undocumented immigrants are relegated to low-wage blue-collar work, Cho (2017) demonstrates that "respective location of principal ethnic niches, and access to these labor market structures, lead to divergent pathways of employment" (p. 97).

LatCrit scholars have long demonstrated the importance of thinking about how race and class work together to produce violence in immigrant communities, showing how immigration officers concentrate their efforts in Latinx working class spaces (Romero 2006; Romero and Serag 2005). While "Latinx" is not a race, being Latinx is highly racialized and often conflated with "Mexicanness" (Chavez 2013). That is, the racial logic of being "Latinx" in the US means that anyone who appears phenotypically "mestizo" "brown"—or of some mixed ancestry of European, African, Indian and or Asian — can be racialized as Latinx (Marrow 2003), especially if they speak Spanish and work in jobs associated with illegality (Flores and Schachter 2018). Further, "looking Mexican/Latinx" carries real consequences as it is the "basis for suspecting criminality under immigration law" such that "Mexican Americans and other racialized Latino citizens and legal residents are subjected to insults, questions, unnecessary stops and searches" (Romero 2006, p. 449). ${ }^{3}$ Of course, not all immigrants from Latin America are racialized in the same way (García 2017; Herrera 2016). Herrera (2016) demonstrates how race shapes experiences of illegality for indigenous and non-indigenous immigrants from Guatemala. While both groups experience institutional and state discrimination, indigenous Guatemalans experience discrimination on the basis of their indigeneity too, including from their non-indigenous Guatemalan peers.

This paper continues to push an intersectional lens that captures how white supremacy is intertwined with capitalism to shape immigrants' lives-but redirects the lens to how marginalization (due to illegality) intersects with racial privilege (due to whiteness). As Collins (1990) argues in Black Feminist Thought, we need to understand not only how multiple forms of marginalization operate, but also how penalty and privilege work together. That is, few are "pure victims or oppressors;" rather "each individual derives various amounts of penalty and privilege from the multiple systems of oppression which frame everyone's lives" (Collins 1990, p. 229). While I primarily focus on race and immigration status in this paper, I also note how gender is salient, shaping how 1.5generation Brazilian men and women accrue the wages of whiteness. 
In the next section, I turn my attention to how the intertwined systems of white supremacy and capitalism have been central to the nation-state project, shaping immigration, citizenship and inclusion policies from the past to the present. Importantly, I not only focus on how the state constructs and values whiteness, but also how previous waves of immigrants have engaged in boundary-making from racialized groups as they worked toward whiteness. Central to this historical perspective is the work of scholar and activist W.E.B Du Bois, whose work on the power of race for whites exploited under capitalism continues to have explanatory power today.

\section{Laws and Boundary-Making: Accruing the Wages of Whiteness in a White Supremacist State}

The Black radical tradition has demonstrated how American wealth, concentrated in the hands of wealthy white elites, was built on a global institution of racial capitalism that provided compensation for whiteness and devalued blackness (Cox 1948; Du Bois 1935; Robinson 2000). In their pursuit of wealth, European colonialists enslaved Black people, dispossessed indigenous people of their lands, and exploited other racialized groups defined as undesirables. The intertwined systems of white supremacy, capitalism, and patriarchy were at the heart of the nation-building projects of the United States and countries throughout Latin America, shaping the social institutions and citizenship policies which would determine who could migrate, who gains access to citizenship, and who gains access to the full benefits of citizenship (Hernández 2012; Jung 2015). Importantly however, throughout history, it was not just elites who had a hand in perpetuating racist oppressionmarginalized groups also played an active role in creating the practices that sustain white supremacy (Bashi Treitler 2013; Ignatiev 1995; Roediger 1991). That is, ethnic groups have often engaged - and continue to engage-in explicit boundary-making from Blacks and other stigmatized racial groups in order to achieve "racial uplift" (Bashi Treitler 2013). But only some groups, especially European ethnic groups, have been successful in accruing the wages of whiteness (Bashi Treitler 2013; Du Bois 1935; Roediger 1991).

In the United States, race, class and gender have been foundational to legal and social membership since the very beginning. The nation's first citizenship law-the Naturalization Act in 1790-limited citizenship to "free white men" (Hing 2004; Ngai 2004). Blacks gained the right to naturalization after slavery ended, but the racial requirements for citizenship were not fully lifted by Congress until 1952. While Blacks were given formal access to citizenship, laws, policies and practices rooted in white supremacy continue to deny Black folks full inclusion. These laws and practices include Jim Crow Segregation laws in the U.S. South (before Civil Rights Acts made those laws illegal), racist housing and hiring policies, assaults on voting rights, "the war on drugs," mass incarceration, and white flight from cities into the suburbs to avoid integrated neighborhoods and schools (Alexander 2012; Bonilla-Silva 2017). Thus, legal citizenship never guaranteed access to the full benefits of citizenship for Black Americans.

For immigrants who came to the US throughout the 19th and early 20th centuries, seeking opportunity in the factories in the northeast, the railroads out west, and in agriculture in the south, whiteness was paramount for reaping the promises of "the American Dream." However, who could be considered 'white' was always contested. Elites sought to narrow the boundaries of whiteness (Ngai 2004) while immigrant groups often worked toward whiteness, with varying degrees of success (Bashi Treitler 2013; Brodkin 1998; Ignatiev 1995; Roediger 1991). Even the Supreme Court weighed in on who could be considered white. In 1922, the Supreme Court argued that Takao Ozawa, a Japanese American, was not white because "the best science" said he was of the "Mongolian race". Later, the Supreme Court reversed their own logic in the case of Indian American and WWI war hero Bhagat Singh Thind-arguing that while scientists might attest to Thind's whiteness, Thind was not white because the "the common man" does not include Indians as white (Ngai 2004). For Indian Americans, this ruling was devastating, as they were retroactively stripped of citizenship and land. As historian Mae Ngai (2004) points out, there were many persons who challenged the racial requirements for citizenship —and nearly all argued that they 
should be considered white—not Black, even though Blacks in the 1920s were also eligible for citizenship.

Being deemed legally white, however, did not necessarily ensure social whiteness. After the Treaty of Guadalupe Hidalgo ended the Mexican American War in 1848-a war which began when white American settlers invaded Mexican lands-Mexicans who had been living in what is the present-day American Southwest were offered American citizenship. Due to the white racial requirement for citizenship at the time, Mexicans who stayed were considered legally white. While legally white, Mexicans, many of whom were descendants of Spaniards, were socially deemed non-white and subjected to racism and segregation from whites in the American southwest, akin to what Blacks experienced under Jim Crow laws in the South (Donato and Hanson 2012; Gutiérrez 1995).

Yet, as was true for other racialized groups, some Mexicans living in the American southwest still worked toward whiteness in their new national context, engaging in boundary-making from more stigmatized racial groups (Bashi Treitler 2013). For example, after the 1930 Census enumerators treated Mexicans as Black equivalents, some Mexican groups formed and distanced themselves from Blackness, emphasizing their European roots. As Rodriguez (2008) argues, Mexicans learned to "negotiate the Anglo American racial hierarchy to their advantage" and were often "crass in their efforts to disassociate themselves from Blacks" (p. 173, 174). Nevertheless, the legacy of this long history of discrimination and racism toward Mexican-Americans in the American southwest continues today — and even light-skinned Mexican Americans find themselves under "scrutiny," experiencing "racial profiling and discrimination" (Dowling 2015, p 119).

Immigrants from Ireland and Southern and Eastern Europe also learned the value of a white racial identity. Upon arrival in the 1800s and 1900s, these groups often worked in oppressive labor conditions and faced anti-immigrant hostility and discrimination (Bashi Treitler 2013; Roediger 1991). Throughout the 1800s, however, there were few restrictions on their migration - and because they were legally considered white, they had relatively easy paths to citizenship once in the United States (Ngai 2004). While their whiteness was not always a "given," laws helped construct their whiteness, even discriminatory laws. For example, while the National Origins quota laws of the 1920s sought to limit migration from Eastern and Southern Europe, these laws ultimately reaffirmed southern and eastern Europeans racial identities as white as their migration was limited, but not excluded altogether (Ngai 2004).

While laws played a role in constructing their whiteness, so did white immigrants own actions. Scholar and activist W.E.B. Du Bois (1935) firmly placed race—or "the colour line" at the heart of US capitalist development and argued that whiteness was so powerful for white ethnics in the 1800s and early 1900s that they would choose poverty over equality with Black folks. He demonstrated how white workers like the Irish fought-and even killed-for the racial compensation of whiteness, even when it did not help their economic interests. For example, in Philadelphia, white workers helped to strip blacks of voting rights and joined white mobs rioting and killing Black folks (Du Bois 1899). In the American South, after Black resistance helped end the institution of slavery, poor white workers refused to join in solidarity with freed blacks against white capitalists (Du Bois 1935).

In Black Reconstruction, Du Bois (1935) argued that in some circumstances, white laborers received material wages that were high in comparison to Black laborers and to the rest of the world. He also noted, however, that sometimes, even when their material wages were not high, they were compensated by the public and psychological wages of whiteness, which kept white workers from choosing solidarity with Blacks.

"The white group of laborers, while they receive a low wage, were compensated in part by a sort of public and psychological wage. They were given public deference and titles of courtesy because they were white. They were admitted freely with all classes of white people to public functions, public parks and the best schools. The police were drawn from their ranks, and the courts, dependent upon their votes, treated them with such leniency as to encourage lawlessness. Their vote selected public officials and while this had small 
effect upon the economic situation, it had great effect upon their personal treatment and the deference shown them. The newspapers specialized on news that flattered the poor white and almost utterly ignored the Negro except in crime and ridicule".

(Du Bois 1935, p. 700-1)

Thus, for Du Bois, race and capitalism cannot be disconnected-as the systems of white supremacy and capitalism are intimately intertwined. In this way, the benefits of whiteness are not just a kind of "privilege" but a form of compensation-as whites receive compensatory public and psychological wages for whiteness, even if as workers, they can be materially exploited. Specifically, Du Bois specified that the public wages of whiteness in the 1800s and early 1900s took the forms of "public deference and title of courtesy" and access to "public functions, public parks" and "the best schools." These public wages also brought about psychological wages of whiteness. Building off the work of Du Bois, Roediger (1991) shows how the Irish not only actively constructed a working class identity, but a white working class identity to differentiate themselves from Black people. In so doing, Roediger (1991) argues that Irish laborers used the "statuses and privileges conferred by race" in order "to make up for alienating and exploitative class relationships" (Roediger 1991, p.13). Thus, European white ethnics did not just benefit from Congressional laws that placed the boundaries of whiteness around them (although they did), they also actively worked toward whiteness—engaging in boundary-making, especially from Black people (Bashi Treitler 2013; Brodkin 1998; Ignatiev 1995; Roediger 1991).

In the contemporary era, scholars have demonstrated that immigrants continue to engage in identity boundary work (Browne et al. 2021). But to what extent does this historical scholarship on the wages of whiteness apply for undocumented immigrants today? To examine whether-and how-the wages of whiteness operates for 1.5-generation Brazilians, we must consider similarities and differences between past and present.

On the one hand, working-class Irish and Southern and Eastern European immigrants during the 1800s/early 1900s and white-passing undocumented Brazilians in the contemporary era both face(d) anti-immigrant sentiment from nativist groups and exploitation in the labor market. And yet, despite this discrimination and capitalist exploitation, they both live(d) in a national context in which whiteness was/is central for membership in society. Today, white supremacy often operates in public and institutional spaces via more covert practices, but ultimately, white racism continues to ensure that race shapes where residents live, work, go to school, and play-with whites hoarding the best spaces and resources (Bonilla-Silva 2017).

On the other hand, key differences between then and now also exist. First, white ethnics of the past had a relatively easier path to naturalization, and thus, were unlikely to be undocumented. With citizenship, they gained political power as a key voting block (Roediger 1991). Second, ramped-up immigrant enforcement has increased the insecurity of a precarious immigration status, making immigrants today more vulnerable to deportation (De Genova 2002; Golash-Boza 2011, 2015).

\section{The Case of 1.5-Generation Brazilians in Massachusetts}

One-and-a-half generation Brazilians who migrated to Massachusetts during the 1980s and 1990s present a good case for examining the wages of whiteness in the contemporary era as many Brazilians who migrated to Massachusetts during this time are undocumented and light-skinned. In 2007, the year after my longitudinal research project began, Marcelli et al. (2008a) reported that 70\% of all Brazilians in the Boston metro area were undocumented. In comparison to other immigrant groups in the area (such as Dominicans), Brazilians were also much more likely to have light skin (Marcelli et al. 2008a, 2008b).

Brazilians who came to Massachusetts during the 1980s and 1990s were part of the first large wave of Brazilian migrants to the US and primarily came from middle-class families. Given Brazil's history of colonization, it is not surprising that middle-class Brazilians also tend to be disproportionately light-skinned. As in the United States, Brazil 
has a long history of white supremacy and anti-Blackness. Portuguese colonialists to Brazil displaced indigenous populations, forced Africans into slavery, and later, after independence, encouraged European migration to Brazil in an effort to "whiten" their population in the name of "development." Through this whitening strategy, laws and policies gave European immigrants (and their descendants) access to migration, land and better jobs in Brazil (Hernández 2012). Today, white Brazilians remain over-represented in positions of political, economic and cultural power. While many Brazilians believe the myth that Brazil is a "racial democracy" where "money whitens", research suggests that non-white Brazilians are systematically blocked from mobility into the middle class (Telles 2004).

Until the 1980s, few Brazilians emigrated. Following an economic collapse in Brazil, however, middle-class Brazilians, whose standards of living were jeopardized, left for the US (Goza 1994; Margolis 1994). But unlike European immigrants of the past, these middle-class Brazilians and their children have faced greater barriers to lawful immigration and citizenship due to changes in federal immigration policies. While the Hart Cellar Act of 1965 opened up migration steams to the US from Asia, Africa and Latin America-it also placed numerical limits on migrants from the Western hemisphere and individual country limits-creating more "undocumented migrants" from these areas (Johnson 2003). Furthermore, these restrictions on migration have been coupled with few pathways to citizenship. Indeed, the Immigration Reform and Control Act (IRCA) in 1986 was the last time the Federal Government provided large-scale opportunities for undocumented immigrants to adjust their status. Brazilians who came during or after the mid-1980s would have migrated too late to benefit from IRCA.

In this restricted migration policy context, most middle-class Brazilians in the 1980s and '90s lacked the family connections and/or skills necessary to facilitate lawful immigration. Thus, most entered the US on tourist visas and overstayed/violated the terms of their visas, becoming undocumented (Cebulko 2014). For light-skinned, middle-class Brazilians, migration to the US was largely a strategy to maintain their positions in global racial-economic hierarchies (Cebulko 2013), especially as many never intended to stay permanently in the US (Margolis 1994).

Without lawful immigration status, however, many first-generation Brazilians experienced downward mobility in the US, working in housecleaning and other low-wage service sector jobs (Margolis 1994). First-generation Brazilians also discovered that while they often considered themselves white in Brazil, constructions of whiteness were different in the US. Working in low-wage service sector jobs associated with Mexicans and other Latinx groups, many first-generation Brazilians were cialized as Latinx, much to their dismay (Beserra 2005; McDonnell and de Lourenço 2009). According to Beserra (2005), some first-generation Brazilians assert "Brazilian" as their race in the US to distance themselves from being racialized as Latinx.

In contrast to their first-generation parents, 1.5-generation Brazilians are socialized in American schools and speak English more fluently (and often, without an accent), which makes it easier to pass as white (Cebulko 2013). But while they might pass as white, many 1.5-generation Brazilians also say that they are sometimes racialized as Latinx and/or Arab depending on how tan they are, who they are with, how they are wearing their hair, and what they are wearing (Cebulko 2013). Thus, as discussed later, 1.5-generation Brazilians often actively construct their whiteness in order to accrue its wages. Importantly, their experiences are unlikely to be similar to the experiences of more recent Brazilian arrivals, as poorer and darker-skinned Brazilians and their children have migrated in greater numbers since 9/11 (Braga and Jouët-Pastré 2008).

To be sure, successful constructions of whiteness may help 1.5-generation Brazilians avoid the very real threat of deportation in the contemporary era. Between 1997 and 2015, approximately five million people were deported, more than two and a half times the number of persons deported in all the years prior to 1997 (Golash-Boza 2015). Yet, not all immigrants are equally vulnerable to deportation—as the US government disproportion- 
ately deports undocumented men from Latin American countries and Black men from the Caribbean with lawful permanent residency (Golash-Boza 2011, 2015; Golash-Boza and Hondagneu-Sotelo 2013).

\section{Methods}

Data primarily comes from in-depth interviews with twenty-nine 1.5-generation, Brazilians-21 women and 8 men-who identify as white or can pass as white and who experienced illegality in young adulthood. The interview data comes from a larger study of interviews with fifty-five 1.5-generation and second-generation Brazilians. Interview data was supplemented with non-continuous fieldwork over the past 15 years. In 2006, I temporarily moved to Massachusetts and in 2007 I began working for one local Brazilian non-profit organization as their Development Coordinator, planning their annual fundraiser. Additionally, I started working as a periodic Grant Consultant for another grassroots Brazilian organization. Since 2007, I have mostly lived in Boston or the greater Boston metro area (which extends into other New England states), visiting interview respondents' homes, workplaces, and local hang-out spots. Many respondents stayed in contact long after the interviews ended, as I helped them, at times, gain more information about legislation, policies, and/or the rights associated with their immigration status.

A snowball sample was used, with staff at the non-profit organizations serving as my first contacts for identifying potential respondents. Of the twenty-nine respondents who could pass as white and experienced illegality in adulthood, eighteen participated in more than one interview. The first wave of interviews was conducted between 2006-2008 and a second wave was conducted from 2011-2013 (which included interviews with new respondents and former respondents). After 2014, I kept in touch with a dozen of the respondents who were still experiencing precarious illegality, some participating in formal interviews, including during and following the election of Trump.

Interview topics included questions about their families' lives back in Brazil, migration and settlement experiences in the US, their perceptions on how illegality has shaped their lives, their perceptions of racial hierarchies in the US and Brazil, and their own ethno-racial identities and sense of belonging. During the interviews, I asked about race in a number of ways, including how they racially identified themselves on forms (and their frustrations with the process), their perceptions of how they believed others perceived them (including when walking on the street), and what they believed their race was in Brazil. I also wrote down descriptions of some of their phenotypical features-including hair color and texture, eye color, and skin color. Underscoring that race is a social construction, nearly all of the respondents indicated that how they were perceived racially by others was highly fluid, changing based on how they chose to style their hair (curly or straight), how tan their skin was, what they decided to wear, and who they were hanging out with.

I classified respondents as white or white-passing if they said during the interview (1) that they were always perceived as white, (2) if they described themselves as racially ambiguous, but said that they could be-or had been-racialized as Eastern or Southern European, and/or (3) they described themselves as racially ambiguous and I observed them to be successfully white-passing in any of our interactions. ${ }^{4} \mathrm{I}$ also limited the study to those who did not have a green card when they turned 18 , as scholars agree that illegality becomes more salient in their lives in young adulthood. ${ }^{5}$

Interviews were transcribed and then coded, as I searched for patterns and emergent themes. As these patterns emerged, I then looked for negative cases in order to confirm or contradict emerging propositions (Rizzo et al. 1992). Most respondents reported that they faced barriers to socioeconomic mobility and, at times, anxiety due to their precarious immigration status. However, as detailed in the next sections, they also experienced the public and psychological wages of whiteness-which at times, facilitated real social and material gains. The mechanisms by which they experience these wages involves assumptions of white innocence, racial solidarity from other white Americans, and their own active 
work toward whiteness. In the next sections, I examine each of these mechanisms before turning attention to the implications of the public and psychological wages of whiteness.

\section{Results and Discussion \\ 6.1. "I Can Get Away with Murder Because I'm That White:" Assumed Innocence as White/White-Passing}

One of the primary mechanisms by which white-passing undocumented Brazilians experience the public and psychological wages of whiteness is through the conflation of whiteness with innocence, a phenomenon that is especially true for white women (Christie 1986; Collins 1990; Wanzo 2008) who have strategically used innocence to uphold white male patriarchy in settler-colonial societies (Hamad 2019). This assumed innocence by others-which provides white immigrants with the benefit of the doubt-is articulated most strikingly by Elisabete, who exclaimed during our interview "I can get away with murder because I'm that white. It's sad, but true".

To illustrate the power of assumed innocence that came with whiteness, Elisabete told me a story of causing a car accident in her pre-DACA life. Driving without a license, she hit a cyclist, just a few blocks from her home. The police showed up to the scene of the accident. Elisabete was not someone overwhelmed by fears of deportation, but she was nervous when the police arrived, suggesting she experienced what Enriquez and Millán (2019) refer to as a "situational trigger" of deportability. When Elisabete told the police officer "I don't have my license with me", he treated her nicely, telling her to head home, assuming she would be able to produce a license. But eventually, at her home, Elisabeth had to tell the police officer the truth: she could not produce the license because she did not have one. Still, the police officer was kind. He did not arrest her and he did not turn her over to immigration authorities. Instead, the police officer told her he was issuing a ticket and that she would need to arrive in court. However, he also reassured her, telling her not to worry about further repercussions.

Elisabete's assumed innocence as white continued to benefit her once she arrived in court. She recalled the reaction of the judges, court recorders, and media to her, saying they were shocked that the undocumented immigrant who had hit the American citizen was white, not brown. "There was an audible gasp in the room when I stood up" she said. Elisabete was very aware that her whiteness benefited her in those interactions. "My picture never showed up in any paper" she told me, believing that had she not appeared white, the media would have had pounced on a story of a brown undocumented immigrant who harmed a US citizen. Given the role of the media in constructing a "Latino Threat Narrative" (Chavez 2013), she is not wrong.

Importantly, it was not just light-skinned Brazilian women who reported benefitting from assumed innocence in interactions with enforcement officials. Ricardo, a tall and athletic young man, told me a story from when he was in college. Driving on the highway with his white rugby teammates in upstate New York, Ricardo noticed that the border patrol were stopping every car on the highway. Like Elisabete, Ricardo was nervous, especially because he was "fully" undocumented at the time and did not have a license. Moreover, none of his white teammates knew about his immigration status. Like Elisabete, however, Ricardo was fine. When border patrol looked in the car, they let Ricardo and the other young men continue without providing documentation. Underscoring the power of his whiteness, Ricardo told me that things would have been different "had (he) looked distinctly Guatemalan or something ... "While brown-skinned Latinx immigrants and their descendants are marked as "undocumented" and as "criminals" —and disproportionately stopped, searched, detained and deported (Chavez 2013; Schmalzbauer 2014)_Rodrigo was not even asked for a license by border officials.

Both Elisabete and Ricardo recounted specific interactions with police and other enforcement officers in which the assumptions of white innocence allowed them to escape serious consequences. However, many 1.5-generation Brazilians I interviewed reported very few interactions with the police. This is not surprising, given my own experience in public spaces with respondents over the past fifteen years. While some respondents 
chose to meet at Brazilian restaurants or their homes, many respondents asked me to meet them at their favorite dining spaces and hang-outs, spots which were non-Brazilian owned. This included fancy dinners at high-end steak restaurants, drinks at trendy college bars in the Boston College and Harvard neighborhoods, and coffees at local, white-owned coffee shops and/or bookstores. These establishments and neighborhoods were not heavily policed, and respondents' whiteness did not raise suspicion among the workers or other customers. Thus, when Tatiana told me "I don't have a lot of experience with the police," it was not terribly surprising. Tatiana and other white-passing Brazilians benefited from being seen as "innocent" by police, border security and, as seen in the next section, by other white Americans.

\section{2. "She's White. What Are Talking about? Go Talk to That (Brown) Guy!" White Racial Solidarity from Other Whites}

Another mechanism that facilitates the public and psychological wages of whiteness for undocumented white-passing immigrants is white racial solidarity from other white Americans. Over the past few years, the news has been filled with stories of white Americans calling the police on Black people-for bird watching in Central Park, sleeping in cars, etc. Citizenship, higher incomes, and middle-class neighborhoods do not protect Black Americans from police brutality nor from white civilians calling the police on them and their children (Clerge 2019). But in stark contrast to these stories of white vigilantes, some undocumented white-passing 1.5-generation Brazilians reported benefiting from white racial solidarity from complete strangers in public spaces.

Ana Maria, whose ancestors migrated from Germany to Brazil in the mid-1900s, provided the most vivid example of white racial solidarity from complete strangers. In the months after 9/11, Ana Maria took a trip to Oklahoma. Going home to Massachusetts through airport security, airport security officials flagged her passport (which lacked the proper stamps) and asked her for her green card. Ana Maria was petrified that her life in the US was coming to an end. However, a white American stranger, just behind her in line, intervened and redirected security agents' attention to an Arab-looking man who had already gone through security.

"The guy in front of me was a male, and he was like Arabian or something. Um, and he didn't get searched or anything. He didn't get looked at. I come to the line, and I get asked for my green card. And I'm like "Oh, I don't have my green card on me" and this and that ... And the guy behind me, he's like "what are you talking about, man? She's white. What are talking about? Go talk to that guy (the man in front of her)."

White racial solidarity from the stranger in line may have prevented Ana Maria's detention and deportation that day. Indeed, the white American man assumed that Ana Maria was a "real American" as a white person, innocent of any wrong-doing, while demanding that security agents question the belonging of a man he racialized as a dangerous other.

\section{3. "I Don't Want to Be Compared with a Mexican:" Distancing from Racialized Groups and Constructing Whiteness}

As the earlier stories reveal, the public wages of whiteness provide access to public space, without facing serious consequences, including arrest, detention and deportation. Importantly, however, accruing the wages of whiteness is not a passive process. Just as previous waves of immigrants worked toward whiteness, so do 1.5-generation Braziliansand they often do so through boundary-making from other stigmatized racial groups (Brodkin 1998; Ignatiev 1995; Roediger 1991). For Gabriella, this boundary-making plays out in her refusal to identify as Hispanic or Latina because she does not want to be "compared with a Mexican."

Often, 1.5-generation Brazilians accrued these wages through their families' boundary work-especially in decisions to avoid living and sending their children to school in Black and Brown spaces, spaces which are more heavily policed (Alexander 2012; 
Fagan et al. 2015). For example, Álvaro explained how racism shaped his parents' schooling decisions for him.

My parents were scared of sending me to School X because it was in Dorchester. And then, School Y, was in Roxbury and they didn't like the neighborhoods.

Álvaro uses "Dorchester and Roxbury" as code for "Black spaces." In 2010, census tracts in the areas surrounding School X and School Y were more than $60 \%$ Black (and in some tracts, more than 70\% Black). Meanwhile, Álvaro's parents chose to raise him in a Boston neighborhood which was nearly $60 \%$ White. Álvaro's situation and perspective was not unique. More than $70 \%$ of respondents reported growing up in areas and neighborhoods that were working-class white neighborhoods and/or socio-economically and culturally diverse spaces, including the neighborhoods surrounding Boston's many colleges and universities. Thus, part of the reasons my respondents are less policed is because their families often made decisions to live and send their children to school in white-majority areas and schools. But of course, as discussed in the previous section, 1.5-generation Brazilians not only avoid arrest, detention and deportation because they live and go to school in white-majority neighborhoods that are less likely to be policed; they can also pass as white, marking them as "innocent", not as "illegal" nor "criminal."

Because some respondents were racially ambiguous, they sometimes engaged in careful self-presentations as white, self-presentations that were also gendered. Leila was one of those individuals. If she were walking on the street-wearing tight jeans and hoop earrings - she believed that many strangers would perceive her as Latina. And when Leila went clubbing with her immigrant friends, she embraced presenting herself this way. In other situations, however, especially when interacting with state bureaucrats and/or authorities, Leila actively worked toward presenting herself as white. For example, in the late 2000s, prior to DACA, undocumented young persons were denied access to drivers licenses in Massachusetts. However, Leila had been able to secure a license when living out-of-state. When she went to the Registry of Motor Vehicles in MA to change the state of residence for this license-and later to renew it-Leila actively constructed whiteness in order to feel more confident.

When I walk into the RMV, I am going to straighten my hair, I'm going to wear my glasses, I'm going to talk as white as I can. You know? And I'm just going to walk in there and I'm going to say that I need to renew my driver's license or whatever... And sound as white as possible (talks in a higher-pithed and slower tone)... As ridiculous as it sounds, like, it (passing as white) just makes me feel more comfortable about what I'm doing. You know?"

Leila's efforts underscore at least two things. First, accessing the public and psychological wages of whiteness does not just "happen" for all white-passing Brazilian immigrants. In Leila's case, she consciously engages, at times, in a gendered self-presentation as white by straightening her hair, wearing glasses and talking in certain ways (Goffman 1959). Second, whiteness not only provides her with public wages, but psychological wages-increased comfort-which facilitated access to important documents for her mobility (a driver's license). Further, as seen in the next section, Leila was not the only one who experienced and took advantage of these psychological wages. For some 1.5-generation Brazilians, the psychological wages of whiteness even led to risky behaviors and/or more limited fear of detention/deportation than we might otherwise anticipate given their illegality.

\subsection{Confidence and Risk-Taking in Everyday Interactions}

While deportability is theorized as a key factor of migrant illegality, Enriquez and Millán (2019) argue that it is a "situationally triggered fear that is reduced when individuals occupy protective social and spatial locations that limit their exposure to immigration enforcement mechanisms" (1). Furthermore, they argue that the more protective social and spatial locations one occupies, the less salient deportability is. To be sure, some undocumented 1.5-generation Brazilian immigrants experienced "situational triggers"—growing 
anxious in the presence of police and border patrol (like Elisabete and Ricardo's stories, above). However, I also find that some undocumented, white-passing 1.5-generation Brazilians are much less fearful of these interactions due to the psychological wages of whiteness.

For example, eighteen-year old Thais described the police as "funny" and "nice." She explicitly told me that the police did not suspect her to be undocumented. Thais is beautiful, conforming to Eurocentric notions of beauty with her light-skin that tans easily in the sun, her bright brown eyes and straightened hair. Her positionality as an attractive, young, light-skinned woman shaped her interactions with the police, who she said "play(ed) jokes" with her and other Brazilian women.

"We know all of (the cops). They all play jokes with us. 'Oh, Brazilians! We love Brazilians! They're the most beautiful women in the world!' You know, they're really funny and nice. They're like 'every time you have a problem.' But it's this kind of thing- they're nice to us, but I'm pretty sure they don't know our status. If they knew our status, they probably wouldn't be as nice as they are right now, you know what I mean? So they're like 'Oh if you guys have any problems, just let us know and if we can help with tickets and stuff.' You know when you get a friendship with cops, and they're like 'ok'. When we got this ticket, I was like, 'Mom, tomorrow I work, the first thing we do-I'm going to talk to them and see what they're going to do about it, right?'"

Stereotypes of "beautiful (Brazilian) women" were mentioned by many respondents. For Thais, these gendered and racialized stereotypes played a role in her interactions with police officers, interactions that gave her confidence to ask them to forgive her mom's speeding ticket. Her confidence to ask the police for help on this matter is strikingand stands in contrast to stories of immigrants who avoid interactions with government officials, forgoing benefits for themselves and/or their families for which they are eligible (Dreby 2015; García 2018; Sommers et al. 2012).

One of the clearest examples of the psychological wages of whiteness can be seen in the risk-taking behaviors of Roberta and Bianca, twins who traveled to Brazil when they were undocumented. In 2006, the twins had graduated from high school and were frustrated with blocks to their higher education dreams. Feeling like they had, in the words of Bianca, "nothing to lose," they traveled to Brazil for a three month vacation. Despite traveling on passports which clearly demonstrated they had overstayed their visas, the light-skinned twins were fine, passing through customs without incident. Bianca and Roberta almost certainly benefited from white innocence in their interactions with customs agents, especially as light-skinned young women.

But the power of their whiteness in these public places sometimes made them too confident. Three years later, when Bianca tried to enter the US for a second time after a visit to Brazil, she was detained and deported, barred from re-entry for ten years. Thus, whiteness does not always protect Brazilians, as ultimately, their (il)legality rendered them deportable. However, in my fifteen years of research, Bianca was the only respondent deported, and this deportation only came after she had tried to re-enter the United States for a second time, on a passport that showed she had overstayed her visa.

\subsection{Implications for Fear of Detention and Deportation}

While Bianca was the only respondent who was deported, at least five respondents reported that a loved one had been deported, causing emotional and financial harm. Thus, whiteness does not always provide protection from the harmful consequences of deportation. Deportations, especially of mothers and sisters, were particularly painful for respondents. Indeed, Roberta cried throughout our second interview whenever she talked about Bianca, detailing how they were missing out on each other's weddings and raising their children together. Women are often the connectors in families and, for Roberta, not celebrating these gendered lifecourse rituals and experiences with her twin sister was incredibly difficult.

Thus, some respondents had personal experiences with deportation. And yet, few respondents were concerned that they would be directly targeted for detention and depor- 
tation, even as they worried that they may feel compelled to self-deport after Trump was elected. In part, we might explain their lack of fear as a function of their generation-status. Abrego (2011) finds that 1.5-generation immigrants experience illegality more as stigma than as fear. Yet, under the Trump administration, the fear of deportation heightened, including for 1.5-generation immigrants. In a nation-wide survey of DACA beneficiaries, Wong et al. (2019) finds that more than half of DACA beneficiaries reported worrying about their own deportation on a daily basis while more than $70 \%$ of DACA beneficiaries who were parents worried about being separated from their families due to deportation on a daily basis. But while 1.5-generation Brazilians certainly experienced anxiety due to illegality, daily fear of deportation was not pronounced. I argue that this relative lack of fear is linked to the public and psychological wages of whiteness.

If any of the Brazilians I met had reasons to fear deportation- especially after Trump was elected-it was Alexia, a DACA beneficiary whose mother had been deported when she was a teenager during an undercover sting. Alexia was also a new mom (to a US citizen child) and married to an undocumented Brazilian who was ineligible for DACA. But while Trump's election had certainly increased Alexia's anxiety about the fate of DACA, she was not concerned she would be a target for deportation.

When I met her for our third interview, she lived in the first-floor apartment of a Victorian house in an upper middle-class, white suburb. At the time, Alexia's son was just a few months old and her husband was working in construction alongside Trump-supporting Irish co-workers. When I asked Alexia if she was scared about being deported now that Trump was in office, she quickly answered "oh definitely." However, she quickly clarified that she really was not concerned about being a target for deportation. Rather, she was anxious that blocks to legally working and/or health care would lead her to self-deport.

\section{I: Do you get stressed about deportation?}

R: Oh definitely. Not about deportation. Cause I don't think they are ever-like-(going to) come to my house and say 'you're deported!' But it is going to get bad enough-if it keeps like this-that I'm gonna have to self-deport? And I don't want to do that because I love it here. Like, sometimes, I'm like 'ah I hate this place because of, like, health insurance, and taxes, and this.' But it's where I've been living forever. And I feel like I'm just any other citizen that gets their checks and say(s) 'oh fucking crap' and, you know, 'health insurance-oh crap I have to pay this.'

Alexia was certainly anxious about her precarious illegality, but she also makes clear that she does not fear being targeted for detention and deportation. Indeed, in the weeks before our interview, a police officer had stopped her for making an "illegal" left turn. She was anxious when he stopped her. However, as was true for most white-passing respondents who interacted with the police, the officer was "super nice", letting her off with a warning.

Alexia was not alone. Marcos, who, like Alexia, lived in a primarily white neighborhood, also did not express overwhelming fear of deportation after Trump was elected. When we met in 2019, at a cafe in a white suburb of Boston, Marcos told me that he really did not fear the termination of DACA nor being deported. "I have a lot of faith. So I never really thought that would happen."

Enriquez and Millán (2019) find that those who occupy protective spaces (such as college campuses) and who do not fit the stereotype of illegality because of their acculturation in the US (as 1.5-generation) and/or because they identified as Asian (and not Latinx) experience less situational triggers. For 1.5-generation Brazilians in this study, whiteness is a protective social location (as they are seen as innocent) which provides them more access to protective spatial locations (living in whiter spaces), all of which gives them relative confidence when navigating their everyday interactions, reducing the salience of deportability in their lives. 


\subsection{Implications for Navigating the Labor Market}

Being undocumented has consistently been shown to create barriers to socio-economic mobility for 1.5-generation undocumented immigrants. They face legal and financial barriers to college and are often relegated to jobs that do not reflect their years of education (Abrego 2006; Cebulko 2014; Gonzales 2016; Silver 2018). This was certainly true for undocumented white and white-passing 1.5-generation Brazilians. At the same time, whiteness shapes how they navigate a more restricted, but also heavily racialized and gendered labor market. For example, Elisabete, who we previously met, was forced to downgrade her college choice and struggled to find work commiserate with her education after she graduated from college. But after DACA provided Elisabete with a work permit for the first time in her life, she told me that whiteness gave her the confidence to be "ballsy as shit". Specifically, she blindly reached out to a white woman whose resume she saw on the internet in order to network for a corporate job. Despite Elisabete's illegality and lack of corporate experience, she was optimistic that this woman, who had attended the same public college as her, would be able to relate to her as "another white woman" with a shared educational experience.

Elisabete's story highlights agency in the labor market, despite (il)legality (Gleeson 2010). Moreover, her ability to navigate the labor market in this way suggests that she has symbolic racial capital- "a shared white identity" that could facilitate "positive interactions" with other whites (Feagin 2020, p. 16). In Elisabete's case, it facilitated positive interactions with a white woman she did not know. During our interview, Elisabete was very explicit, her confidence in reaching out to this woman was rooted in assumed racial, gender, and class solidarity with this stranger. Indeed, Elisabete's self-described "ballsy as shit" attitude worked-this white woman did relate to her and network for her, helping Elisabete get her first corporate job. Thus, whiteness produced both public and psychological wages for Elisabete-which, combined with her new work permit via DACA, facilitated access to material gains.

For Elisabete, networking with another white woman facilitated material gains once she had a work permit via DACA. For other 1.5-generation Brazilians, whiteness shaped how they navigated the labor market even when they did not have a work permit. For example, Marcelo had dropped out of high school because he believed he could not earn a bachelor's degree as an undocumented immigrant. Yet, he was not relegated to low-wage blue-collar jobs like many "early-exiters" in Gonzales's (2016) study. Instead, he found work as an electrician, a higher-paying skilled trade that has been dominated by white men due to nepotism and racism toward non-whites (Alexander et al. 2014). Specifically, Marcelo drew on his uncle's networks with Irish electricians. Thus, when we met, Marcelo was working in a relatively well-paid skilled trade, despite being undocumented and a high school drop-out.

Elisabete and Marcelo's stories demonstrate how navigating the labor market is shaped not only by (il)legality, but gender and race. Elisabete used racial, gender and educational solidarity with another college-educated white woman to facilitate opportunities in the labor market, while Marcelo drew on gendered family networks to gain access to a skilled trade dominated by white men. Their stories underscore that undocumented Brazilianswith and without work permits-draw not only on co-ethnic networks (Cho 2017), but white networks for labor market opportunities. Nor were Elisabete and Marcelo's stories unique. Indeed, most respondents who were not working in co-ethnic niches were working for white small-business owners. These jobs were often gendered-with several women working in support roles as administrative assistants while others worked as bookkeepers (women), restaurant managers (women), and bartenders (men).

\section{Conclusions}

Whiteness shapes 1.5-generation Brazilians' experiences of illegality and deportability in powerful ways that are different from many of their undocumented immigrant peers. In this way, their stories challenge the master status perspective of illegality, lending support 
to studies which center an intersectional framework (Cebulko 2018; Enriquez 2017; Valdez and Golash-Boza 2020). Illegality absolutely structures their lives in oppressive waysthey do face blocked opportunities to socioeconomic mobility and they are deportable. At the same time, whiteness brings real compensation-in the form of both public and psychological wages that can facilitate access to real social and material gains. In the labor market, 1.5-generation white and white-passing Brazilians not only draw upon co-ethnic networks to find work, but white networks too. These networks are very much gendered, but ultimately, expand the kind of work they can find.

Whiteness also shapes how 1.5-generation Brazilians in this study navigate public space. At times, whiteness gives them confidence to engage with white Americans, public bureaucrats, police officers, and/or security agents to their own benefit. This does not mean that they do not experience anxiety because of their illegality. Indeed, some do experience what Enriquez and Millán (2019) define as "situational triggers," especially if they are pulled over by the police or border patrol officers. However, like the young persons in Enriquez and Millán's (2019) study, they do occupy protective locations reducing the salience of deportability. For respondents in this study, these protective social and spatial locations are connected to whiteness.

To be clear, these findings are not generalizable to all Brazilians in the United States. In fact, given that poorer and darker-skinned Brazilians have increasingly migrated via Mexico since 2001, these findings are especially unlikely to apply to more recent Brazilian arrivals. Given the ethno-racial heterogeneity of immigrants from Latin American nations, future studies should examine whether other undocumented immigrants from Latin America experience the public and psychological wages of whiteness. Nationality is often used as a proxy for race when studying detention/deportation statistics-and to the extent possible, future studies should seek to disentangle race from nationality when examining who is deported to each country and under what conditions they are deported.

Furthermore, future studies should continue to unpack how gender shapes racialized experiences with illegality. While my findings suggest that gender and race matter for how 1.5-generation undocumented Brazilians navigate the labor market, I was unable to demonstrate the impact on earnings. But given what we know about how race and gender shape jobs and earnings, it would not be surprising if undocumented white-passing women earned less than undocumented white-passing men (Restaurant Opportunities Center United 2015). Furthermore, while other scholars have demonstrated the harmful impacts of deporting male breadwinners for families (Golash-Boza and Hondagneu-Sotelo 2013), it was clear for 1.5-generation Brazilians that the deportations of mothers and sisters-who are often the connectors in families-were very painful for women. Due to the small numbers of respondents in this study who experienced deportation of loved ones, it is impossible to make definitive claims about how gender matters for experiences with deportation. Future studies should examine the impacts on individuals and families when mothers, sisters, and daughters are deported.

This study also adds to the scholarship on whiteness, demonstrating how contemporary immigrants can both be exploited under capitalism and actively accrue the wages of whiteness. That is, oppression and power can operate together-and white-passing undocumented immigrants can both be exploited under capitalism and work to sustain the structures of white supremacy in their everyday lives, often through boundary-making away from racialized groups. In this way, 1.5-generation Brazilians' efforts to navigate the racial hierarchy to their advantage in a global racial capitalist system are not entirely different from previous wages of immigrants (Bashi Treitler 2013; Brodkin 1998; Ignatiev 1995; Roediger 1991). While I primarily emphasize how whiteness matters for undocumented 1.5-generation Brazilians, my findings suggest that gender shapes how they accrue the wage of whiteness.

There may very well be generational, ethnic and place differences in the extent to which light-skinned undocumented immigrants are able to accrue the wages of whiteness. Indeed, studies of first-generation Latin American immigrants who thought of themselves 
as white in their home contexts find that they are often excluded from the boundaries of whiteness in the US (Beserra 2005; McDonnell and de Lourenço 2009; Roth 2012). However, their children, even those who are undocumented, may be more successful in their attempts to construct whiteness, especially as they lose accents and/or live and work in spaces not associated with "illegality." Ethnicity and place may also matter. For example, Julie Dowling (2015) finds that even third and fourth generation white-identifying Mexican Americans from Texas report stories of being racialized as Hispanic by border patrol in Mexican-majority places. The large number of Mexican-Americans living there-and the long, aforementioned history of Jim Crow segregation for Mexican-Americans in the American southwest-likely continues to shape those experiences with racialization in those locales. Future studies should examine how other newer immigrant groups from Latin America, especially those from newer-sending countries in the Southern Conecountries like Chile, Colombia, and Argentina, experience illegality and the boundaries of whiteness in localities across the United States.

Funding: The Research was funded by the National Science Foundation Doctoral Dissertation Improvement Grant (4832912), the Department of Sociology at Indiana University, and the Committee on Aid for Faculty Research Grant (510481) at Providence College.

Institutional Review Board Statement: Data from this study came from several studies conducted over the past fifteen years. Data was approved by the Institutional Review Board of Indiana University (IRB \# 06-11128) and the Institutional Review Board of Providence College (IRB \#13-008, IRB \#14-019, IRB 16-023, and IRB 18-035).

Informed Consent Statement: Informed Consent was obtained for all respondents in the study.

Data Availability Statement: Due to privacy concerns, the data are not publicly available but may be available upon request to the author.

Acknowledgments: The author is grateful to all respondents for their participation in this study. The author also thanks Orly Clerge, Zophia Edwards, Trina Vithayathil and the anonymous reviewers for comments on previous versions of this manuscript.

Conflicts of Interest: The author declares no conflict of interest.

\section{Notes}

1 Pseudonyms are used for all respondents.

2 Eligibility for DACA includes: being under age 31 and present in the US on 15 June 2012, living in the US for five years, and arrival in the US before age 16. Eligible recipients also have to have no felony record and need to be in school or have completed at least a General Education Diploma (GED).

3 In 1975, the Supreme Court's decision in United States v. Bringoni-Ponce ruled that "Mexican appearance" "constitutes a legitimate consideration under the Fourth Amendment for making an immigration stop (Johnson 2000).

4 My definition for being "successfully white-passing" rests on two important phenomena. First, I understand whitepassing to not just be a label, but a process. Second, to be "successul" in passing as white, others must perceive you as white, at least in some contexts. For example, when I was at a popular college-hangout, a stranger started flirting with one of the respondents and mentioned her whiteness.

5 Those excluded from this analysis were overwhelmingly second-generation respondents or 1.5-generation respondents who had experienced adjustments in status during childhood or adolescence and thus, were not undocumented during the transition to adulthood when illegality becomes more salient. Only two respondents were excluded because they could not pass as white.

\section{References}

Abrego, Leisy J. 2011. Legal Consciousness of Undocumented Latinos: Fear and Stigma as Barriers to Claims-Making for First- and 1.5-Generation Immigrants. Law \& Society Review 45: 337-70. [CrossRef]

Abrego, Leisy Janet. 2006. 'I Can't Go to College Because I Don't Have Papers': Incorporation Patterns of Latino Undocumented Youth. Latino Studies 4: 212-31. [CrossRef]

Alexander, Karl, Doris Entwisle, and Linda Olson. 2014. The Long Shadow: Family Background, Disadvantaged Urban Youth, and the Transition to Adulthood, 1st ed. New York: Russell Sage Foundation.

Alexander, Michelle. 2012. The New Jim Crow: Mass Incarceration in the Age of Colorblindness. New York: The New Press. 
Bashi Treitler, Vilna. 2013. The Ethnic Project: Transforming Racial Fiction into Ethnic Factions. Stanford: Stanford University Press.

Beserra, Bernadete. 2005. From Brazilians to Latinos? Racialization and Latinidad in the Making of Brazilian Carnival in Los Angeles. Latino Studies 3: 53-75. [CrossRef]

Bonilla-Silva, Eduardo. 2017. Racism without Racists: Color-Blind Racism and the Persistence of Racial Inequality in America, 5th ed. Lanham: Rowman \& Littlefield Publishers.

Braga, Leticia, and Clémence Jouët-Pastré. 2008. Introduction: Interdisciplinary Perspectives on Becoming Brazuca. In Becoming Brazuca: Brazilian Immigration to the United States. Edited by Clémence Jouët-Pastré and Leticia Braga. Cambridge: Harvard University Press, pp. 1-21.

Brodkin, Karen. 1998. How Jews Became White Folks and What That Says about Race in Americ. New Brunswick: Rutgers University Press.

Browne, Irene, Katharine Tatum, and Belisa Gonzalez. 2021. Presumed Mexican Until Proven Otherwise: Identity Work and Intersectional Typicality among Middle-Class Dominican and Mexican Immigrants. Social Problems 68: 80-99. [CrossRef]

Cebulko, Kara. 2014. Documented, Undocumented, and Liminally Legal: Legal Status During the Transition to Adulthood for 1.5-Generation Brazilian Immigrants. The Sociological Quarterly 55: 143-67. [CrossRef]

Cebulko, Kara. 2016. Marrying for Papers? From Economically Strategic to Normative and Relational Dimensions of the Transition to Adulthood for Unauthorized 1.5-Generation Brazilians. Sociological Perspectives 59: 760-75. [CrossRef]

Cebulko, Kara. 2018. Privilege without Papers: Intersecting Inequalities among 1.5-Generation Brazilians in Massachusetts. Ethnicities 18: 225-41. [CrossRef]

Cebulko, Kara B. 2013. Documented, Undocumented, and Something Else: The Incorporation of Children of Brazilian Immigrants. El Paso: LBF Scholarly Publishing.

Cebulko, Kara, and Alexis Silver. 2016. Navigating DACA in Hospitable and Hostile States: State Responses and Access to Membership in the Wake of Deferred Action for Childhood Arrivals. American Behavioral Scientist 60: 1553-74. [CrossRef]

Chavez, Leo R. 2013. The Latino Threat: Constructing Immigrants, Citizens, and the Nation, 2nd ed. Stanford: Stanford University Press.

Cho, Esther Yoona. 2017. Revisiting Ethnic Niches: A Comparative Analysis of the Labor Market Experiences of Asian and Latino Undocumented Young Adults. RSF: The Russell Sage Foundation Journal of the Social Sciences 3: 97-115. [CrossRef]

Christie, Nils. 1986. The Ideal Victim. In From Crime Policy to Victim Policy. Edited by Ezzat A. Fattah. London: Palgrave Macmillan, pp. $17-30$.

Clerge, Orly. 2019. The New Noir: Race, Identity, E Diaspora in Black Suburbia. Berkeley: University of California Press.

Cohambee River Collective. 1977. A Black Feminist Statement. In Words of Fire: An Anthology of African-American Feminist Thought. Edited by Beverly Guy-Sheftall. New York: The New Press, pp. 231-40.

Collins, Patricia Hill. 1990. Black Feminist Thought: Knowledge, Consciousness, and the Politics of Empowerment. Boston: Unwin Hyman.

Cox, Oliver Cromwell. 1948. Caste, Class and Race. New York: Modern Reader.

Crenshaw, Kimberle. 1991. Mapping the Margins: Intersectionality, Identity Politics, and Violence against Women of Color. Stanford Law Review 43: 1241-99. [CrossRef]

De Genova, Nicholas P. 2002. Migrant 'Illegality' and Deportability in Everyday Life. Annual Review of Anthropology 31: 419-47. [CrossRef]

Donato, Rubén, and Jarrod Hanson. 2012. Legally White, Socially 'Mexican': The Politics of De Jure and De Facto School Segregation in the American Southwest. Harvard Educational Review 82: 202-25. [CrossRef]

Dowling, Julie A. 2015. Mexican Americans and the Question of Race, Reprint ed. Austin: University of Texas Press.

Dreby, Joanna. 2015. Everyday Illegal: When Policies Undermine Immigrant Families, 1st ed. Oakland: University of California Press.

Du Bois, W. E. B. 1899. The Philadelphia Negro: A Social Study. Philadelphia: Ginn.

Du Bois, W. E. B. 1935. Black Reconstruction in America, 1860-1880. New York: Anthaeneum.

Enriquez, Laura E. 2017. A 'Master Status' or the 'Final Straw'? Assessing the Role of Immigration Status in Latino Undocumented Youths' Pathways out of School. Journal of Ethnic and Migration Studies 43: 1526-43. [CrossRef]

Enriquez, Laura E. 2019. Border Hopping Mexicans, Law-Abiding Asians, and Racialized Illegality: Analyzing Undocumented College Students' Experiences through a Relational Lens. In Relational Formations of Race: Theory, Method and Practice. Edited by Natalia Molina, Daniel Martinez Hosang and Ramón A. Gutiérrez. Berkeley: University of California Press, pp. 257-77.

Enriquez, Laura E. 2020. Of Love and Papers How Immigration Policy Affects Romance and Family. Berkeley: University of California Press.

Enriquez, Laura E., and Daniel Millán. 2019. Situational Triggers and Protective Locations: Conceptualising the Salience of Deportability in Everyday Life. Journal of Ethnic and Migration Studies, 1-20. [CrossRef]

Fagan, Jeffrey, Anthony A. Braga, Rod K. Brunson, and April Pattavina. 2015. An Analysis of Race and Ethnicity Patterns in Boston Police Department Field Interrogation, Observation, Frisk, and/or Search Reports. Boston: ACLU of Massachusetts.

Feagin, Joe R. 2020. The White Racial Frame: Centuries of Racial Framing and Counter-Framing. London: Routledge.

Flores, René D., and Ariela Schachter. 2018. Who Are the 'Illegals'? The Social Construction of Illegality in the United States. American Sociological Review 83: 839-68. [CrossRef]

García, San Juanita. 2017. Racializing 'Illegality': An Intersectional Approach to Understanding How Mexican-Origin Women Navigate an Anti-Immigrant Climate. Sociology of Race and Ethnicity 3: 474-90. [CrossRef]

García, San Juanita. 2018. Living a Deportation Threat: Anticipatory Stressors Confronted by Undocumented Mexican Immigrant Women. Race and Social Problems 10: 221-34. [CrossRef] 
Gleeson, Shannon, and Roberto G. Gonzales. 2012. When Do Papers Matter? An Institutional Analysis of Undocumented Life in the United States. International Migration 50: 1-19. [CrossRef]

Gleeson, Shannon. 2010. Labor Rights for All? The Role of Undocumented Immigrant Status for Worker Claims Making. Law E Social Inquiry 35: 561-602. [CrossRef]

Goffman, Erving. 1959. The Presentation of Self in Everyday Life, 1st ed. New York: Anchor.

Golash-Boza, Tanya Maria. 2011. Immigration Nation: Raids, Detentions, and Deportations in Post-9/11 America. Boulder: Paradigm.

Golash-Boza, Tanya Maria. 2015. Deported: Immigrant Policing, Disposable Labor and Global Capitalism. New York: NYU Press.

Golash-Boza, Tanya, and Pierrette Hondagneu-Sotelo. 2013. Latino Immigrant Men and the Deportation Crisis: A Gendered Racial Removal Program. Latino Studies 11: 271-92. [CrossRef]

Gonzales, Roberto G. 2011. Learning to Be Illegal: Undocumented Youth and Shifting Legal Contexts in the Transition to Adulthood. American Sociological Review 76: 602-19. [CrossRef]

Gonzales, Roberto G. 2016. Lives in Limbo: Undocumented and Coming of Age in America. Oakland: University of California Press.

Gonzales, Roberto G., and Edelina Burciaga. 2018. Segmented Pathways of Illegality: Reconciling the Coexistence of Master and Auxiliary Statuses in the Experiences of 1.5-Generation Undocumented Young Adults. Ethnicities 18: 178-91. [CrossRef]

Gonzales, Roberto G., Veronica Terriquez, and Stephen P. Ruszczyk. 2014. Becoming DACAmented: Assessing the Short-Term Benefits of Deferred Action for Childhood Arrivals (DACA). American Behavioral Scientist 58: 1852-72. [CrossRef]

Gott, Richard. 2007. Latin America as a White Settler Society. Bulletin of Latin American Research 26: 269-89. [CrossRef]

Goza, Franklin. 1994. Brazilian Immigration to North America. International Migration Review 28: 136-52. [CrossRef]

Greenman, Emily, and Matthew Hall. 2013. Legal Status and Educational Transitions for Mexican and Central American Immigrant Youth. Social Forces 91: 1475-98. [CrossRef]

Gutiérrez, David G. 1995. Walls and Mirrors: Mexican Americans, Mexican Immigrants, and the Politics of Ethnicity, 1st ed. Berkeley: University of California Press.

Hamad, Ruby. 2019. White Tears, Brown Scars. Melbourne: Melbourne University Press.

Hernández, Tanya Katerí. 2012. Racial Subordination in Latin America: The Role of the State, Customary Law, and the New Civil Rights Response. Cambridge: Cambridge University Press.

Herrera, Juan. 2016. Racialized Illegality: The Regulation of Informal Labor and Space. Latino Studies 14: 320-43. [CrossRef]

Hing, Bill Ong. 2004. Defining America Through Immigration Policy. Chicago: Temple University Press.

Ignatiev, Noel. 1995. How the Irish Became White. New York: Routledge University Press.

Johnson, Kevin. 2000. The Case Against Race Profiling in Immigration Enforcement. Washington University Law Quarterly 78: 676-736.

Johnson, Kevin R. 2003. "The Huddled Masses" Myth: Immigration and Civil Rights, 1st ed. Philadelphia: Temple University Press.

Jung, Moon-Kie. 2015. Beneath the Surface of White Supremacy: Denaturalizing U.S. Racisms Past and Present, 1st ed. Stanford: Stanford University Press.

Marcelli, Enrico, Louisa Holmes, David Estella, Fausto da Rocha, Phillip Granberry, and Orfeu Buxton. 2008a. (In)Visible (Im)Migrants: The Health and Socioeconomic Integration of Brazilians in Metropolitan Boston. San Diego: Center for Behavioral and Community Heath Studies, San Diego State University.

Marcelli, Enrico, Louisa Holmes, Magalis Troncoso, Phillip Granberry, and Orfeu Buxton. 2008b. Permanently Temporary? The Health and Socioeconomic Integration of Dominicans in Metropolitan Boston. San Diego: Center for Behavioral and Community Heath Studies, San Diego State University.

Margolis, Maxine. 1994. Little Brazil: An Ethnography of Brazilian Immigrants in New York City. Princeton: Princeton University Press.

Marrow, Helen. 2003. To Be or Not to Be (Hispanic or Latino): Brazilian Racial and Ethnic Identity in the United States. Ethnicities 3: 427-64. [CrossRef]

McDonnell, Judith, and Cileine de Lourenço. 2009. You're Brazilian, Right? What Kind of Brazilian Are You? The Racialization of Brazilian Immigrant Women. Ethnic and Racial Studies 32: 239-56. [CrossRef]

Ngai, Mae. 2004. Impossible Subjects: Illegal Aliens and the Making of Modern America. Princeton: Princeton University Press.

Patler, Caitlin. 2014. Racialized Illegality: The Convergence of Race and Legal Status among Black, Latino and Asian-American Undocumented Young Adults. In Scholars and Southern Californian Immigrants in Dialogue: New Conversations in Public Sociology. Edited by Victoria Carty, Rafael Luévano and Tele Woldemikael. Lanham: Lexington Press.

Pila, Daniela. 2016. 'I'm Not Good Enough for Anyone': Legal Status and the Dating Lives of Undocumented Young Adults. Sociological Forum 31: 138-58. [CrossRef]

Restaurant Opportunities Center United. 2015. Ending Jim Crow in America's Restaurants: Racial and Gender Occupational Segregation in the Restaurant Industry. New York: ROC United.

Rizzo, Thomas A., William A. Corsaro, and John E. Bates. 1992. Ethnographic Methods and Interpretive Analysis: Expanding the Methodological Options of Psychologists. Developmental Review 12: 101-23. [CrossRef]

Robinson, Cedric J. 2000. Black Marxism: The Making of the Black Radical Tradition. Chapel Hill: University of North Carolina Press.

Rodriguez, Gregory. 2008. Mongrels, Bastards, Orphans and Vagabonds: Mexican Immigration and the Future of Race in America. New York: Pantheon Books.

Roediger, David. 1991. The Wages of Whiteness: Race and the Making of the American Working Class. London: Verso.

Romero, Mary, and Marwah Serag. 2005. Violation of Latino Civil Rights Resulting from INS and Local Police's Use of Race, Culture and Class Profiling: The Case of the Chandler Roundup in Arizona. Cleveland: State Law Review, pp. 75-96. 
Romero, Mary. 2006. Racial Profiling and Immigration Law Enforcement: Rounding Up of Usual Suspects in the Latino Community. Critical Sociology 32: 447-73. [CrossRef]

Roth, Benjamin J. 2019. The Double Bind of DACA: Exploring the Legal Violence of Liminal Status for Undocumented Youth. Ethnic and Racial Studies 42: 2548-65. [CrossRef]

Roth, Wendy. 2012. Race Migrations: Latinos and the Cultural Transformation of Race, 1st ed. Stanford: Stanford University Press.

Schmalzbauer, Leah. 2014. The Last Best Place?: Gender, Family, and Migration in the New West, 1st ed. Stanford: Stanford University Press.

Silver, Alexis. 2012. Aging into Exclusion and Social Transparency: Undocumented Immigrant Youth and the Transition to Adulthood. Latino Studies 10: 499-522. [CrossRef]

Silver, Alexis. 2018. Shifting Boundaries: Immigrant Youth Negotiating National, State, and Small-Town Politics. Stanford: Stanford University Press.

Sommers, Benjamin D., Meredith Roberts Tomasi, Katherine Swartz, and Arnold M. Epstein. 2012. Reasons For The Wide Variation In Medicaid Participation Rates Among States Hold Lessons For Coverage Expansion in 2014. Health Affairs 31: 909-19. [CrossRef] [PubMed]

Telles, Edward E. 2004. Race in Another America: The Significance of Skin Color in Brazil. Princeton: Princeton University Press.

Valdez, Zulema, and Tanya Golash-Boza. 2020. Master Status or Intersectional Identity? Undocumented Students' Sense of Belonging on a College Campus. Identities 27: 481-99. [CrossRef]

Wanzo, Rebecca. 2008. The Era of Lost (White) Girls: On Body and Event. Differences 19: 99-126. [CrossRef]

Wong, Tom K., Sanaa Abrar, Claudia Flores, Tom Jawetz, Ignacia Rodriguez Kmec, Greisa Martinez Rosas, Holly Straut-Eppsteiner, and Philip E. Wolgin. 2019. DACA Recipients' Livelihoods, Families, and Sense of Security Are at Stake This November. Center for American Progress. Available online: https:/ /www.americanprogress.org/issues/immigration/news/2019/09/19/474636/ daca-recipients-livelihoods-families-sense-security-stake-november/ (accessed on 6 January 2021).

Zong, Jie, and Jeanne Batalova. 2019. How Many Unauthorized Immigrants Graduate from U.S. High Schools Annually? Migrationpolicy.Org. Available online: https:/ / www.migrationpolicy.org/research/unauthorized-immigrants-graduate-us-high-schools (accessed on 2 January 2021). 